\title{
Indolizine-Based Scaffolds as Efficient and Versatile Tools: Application to the Synthesis of Biotin-Tagged Antiangiogenic Drugs
}

\author{
Marie Arvin-Berod, ${ }^{\dagger}$ Agnès Desroches-Castan, ${ }^{\ddagger}$ Simon Bonte, ${ }^{\dagger}$ Sabine Brugière, ${ }^{\S}$ Yohann Couté, ${ }^{\S}$ \\ Laurent Guyon, ${ }^{\ddagger}$ Jean-Jacques Feige, ${ }^{\ddagger}$ Isabelle Baussanne, ${ }^{\dagger}$ and Martine Demeunynck ${ }^{*}{ }^{\dagger}$ (i)
}

${ }^{\dagger}$ Univ. Grenoble Alpes, CNRS, DPM, 38000 Grenoble, France

${ }^{\ddagger}$ Univ. Grenoble Alpes, Inserm, CEA, BIG-BCI, 38000, Grenoble, France

${ }^{\S}$ Univ. Grenoble Alpes, CEA, Inserm, BIG-BGE, 38000 Grenoble, France

Supporting Information

ABSTRACT: We describe the design and optimization of polyfunctional scaffolds based on a fluorescent indolizine core derivatized with various orthogonal groups (amines, esters, oximes, alkynes, etc.). To show one application as tools in biology, the scaffold was used to prepare drug-biotin conjugates that were then immobilized onto avidin-agarose for affinity chromatography. More specifically, the antiangiogenic drug COB223, whose mechanism of action remained unclear, was chosen as a proof-of-concept drug. The drugselective discrimination of proteins observed after elution of the cell lysates through the affinity columns, functionalized either with the biologically active COB223 or a structurally related inactive analogue (COB236), is a clear indication that the presence of the indolizine core does not limit drug-protein interaction and confirms the usefulness of the indolizine scaffold. Furthermore, the separation of COB223-interacting proteins from human placental extracts unveiled unanticipated protein targets belonging to the family of regulatory RNA-binding proteins, which opens the way to new hypotheses on the mode of action of this antiangiogenic drug.

\section{INTRODUCTION}

During the last decades, the development of orthogonal chemistries $^{1,2}$ opened the way to the conception of molecular scaffolds decorated with orthogonal reactive groups (azide, alkyne, alkene, carbonyl, etc.) and their use for bioconjugations. $^{3-7}$ So far, there are a few heterocyclic platforms, ${ }^{8-10}$ and none with intrinsic luminescent properties. In a previous work, we considered the use of pyridinium ylide-alkyne cycloaddition forming indolizine as fluorogenic coupling methodology. ${ }^{11}$ Indeed, bioactive indolizines are well-known (for a recent review on their chemical synthesis and biological evaluation, see Singh and $\mathrm{Mmatli}^{12}$ ), but new applications have emerged in the fields of fluorescent markers in biology, ${ }^{13-15}$ detection of organic compounds, ${ }^{16,17}$ or material sciences. ${ }^{18}$ Among the different synthetic strategies, we selected the two-step preparation of 1,3,7-trisubstituted indolizines (illustrated in Scheme 1) from easily accessible reactants (pyridine, alkylating agent, and propiolic ester or amide) and simple reaction conditions. The three partners of the reaction were thus optimized, and in particular, the study pointed to the importance of the electron-withdrawing character of the $R_{1}$ group.

With these results in hand and to go further toward biochemical or biological applications, we decided to exploit the pre- and postfunctionalizations of these 1,3,7-trisubstituted indolizines in an effort to design versatile multipodal scaffolds containing various orthogonal groups. As a proof of interest, the methodology was next applied to the synthesis of biotin-drug conjugates, very useful reactants for affinity chromatography. As a matter of fact, we recently described ${ }^{19}$ the synthesis and biological evaluation of a series of antiangiogenic molecules whose leader compound (COB223) is shown in Figure 1 along with the inactive analogue COB236. COB223 inhibits the vascular endothelial growth factor (VEGF) signaling pathway downstream of Ras and upstream of extracellular signalregulated kinase $1 / 2(\mathrm{ERK} 1 / 2)$ phosphorylation; however, we were unable to pinpoint its exact molecular target.

To go further into the identification of the intracellular target of COB223, we decided to perform the affinity chromatography of placental extracts (placenta is the most highly vascularized tissue in human body and is easily accessible) on a COB223modified agarose gel column. To do so, we needed a biotinylated derivative of COB223 for immobilization onto avidin-agarose columns. However, it turned out that modifying COB223 was not so straightforward due to the presence of several nucleophilic centers and to its high polarity that

Received: October 18, 2017

Accepted: November 28, 2017

Published: December 27, 2017 
Scheme 1. Two-Step Synthesis of Indolizines ${ }^{11}$<smiles>[R]OC(C)=O</smiles><smiles>[R]OCC1CCCC1</smiles>

$\mathrm{R}_{1}=\mathrm{CN}, \mathrm{COCH}_{3}, \mathrm{CONHPr}$, $\mathrm{R}_{2}=\mathrm{OMe}, \mathrm{NHPr}$ $\mathrm{R}_{3}=\mathrm{OEt}, \mathrm{NHBn}$

tested antiangiogenic agents

drug-biotin conjugates
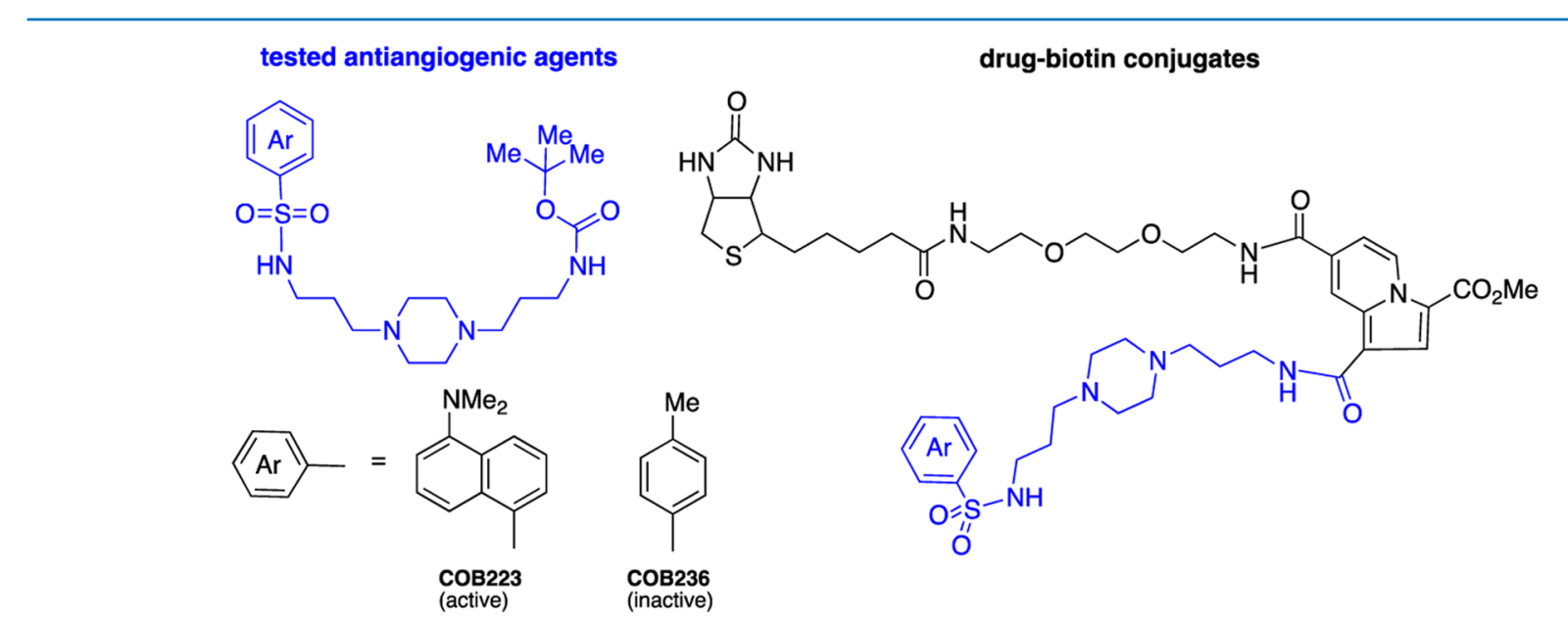<smiles>CC(=O)C[n+]1ccc(Br)cc1</smiles>
ylide

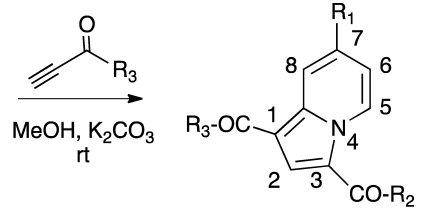
CO-R

Figure 1. Antiangiogenic agents ${ }^{19}$ and their biotin-tagged analogues.

complicated isolation and purification. Designing an original synthetic procedure for biotin-tagged drugs based on the indolizine scaffold was an appealing option.

We report here the chemistry of 7-acetyl- and 7carboxamidoindolizines as potential multifunctional platforms. Various orthogonal groups (esters, amines, alkoxyamines, alkynes) were introduced at positions 1,3 , and 7 of the indolizine rings, by either pre- or postfunctionalization to illustrate the variety of reactions that may be performed. The most suitable methodology was applied to the synthesis of two biotin-tagged antiangiogenic drugs. To evaluate the possible impact of the indolizine nucleus on drug-protein interaction, the biotin-tagged molecules were immobilized onto streptavidin agarose beads and used for affinity chromatography and subsequent proteomics analysis. The comparison of the data obtained using either the biologically active drug (COB223) or the inactive analogue (COB236) is discussed.

\section{RESULTS AND DISCUSSION}

The indolizines shown in Scheme 1 contain three points of modification, each of them coming from one of the three reactants: $R_{1}$ from the pyridine, $R_{2}$ from the alkylating agent (halogeno acetic ester or amide), and $\mathrm{R}_{3}$ from the activated alkyne (propiolic ester or amide). Two strategies were envisioned for the introduction of functional groups: either before cyclization (prefunctionalization) by synthesizing modified starting reactants, or after cyclization (more versatile postfunctionalization). Choosing between the two approaches would mainly be dependent on the stability and orthogonality of the different functions, and on the efficiency of isolation and purification.

7-Acetyl Indolizine 3 was first evaluated as a potential tripodal scaffold (Scheme 2A) with methyl ester and two "clickable" functions (alkyne and carbonyl) for further postfunctionalization. The triple bond may either be introduced using the propiolic amide 2 as dipolarophile ${ }^{20}$ or via formation of the reactive para-nitrophenyl ester $5^{21}$ followed by substitution with propargylamine. Next, the reaction with alkoxyamines (illustrated by benzyloxyamine) yielded the corresponding oxime 4 .

In this first example, the amino group (i.e., propargylamine) was introduced at position 1 of the indolizine ring; however, it was also valuable to link amino groups to other positions. Indolizines 8, 9, and 12 contain the amino groups (illustrated by propylamine, see Scheme $2 \mathrm{~B}$ ) at position 3 . To do so, the corresponding 2-bromo- $\mathrm{N}$-propylacetamide was used as alkylating agent in the preparation of the pyridinium salt $(7$ or 11$) .{ }^{11}$ Two strategies were then evaluated. To form the indolizine 8 , the rather stable ethyl ester was introduced at position 1 by reacting ethyl propiolate with 7 . The oxime bond was later formed to give 9 . In the case of indolizine $\mathbf{1 2}$ bearing reactive para-nitrophenyl ester, the oxime bond was formed in excellent yield at an earlier stage, i.e., before alkylation with the 2-bromo$\mathrm{N}$-propylacetamide and cyclization with the para-nitrophenyl propiolate 5. Lastly, the amino group (exemplified by the mono-Boc-protected 2,2'-(ethylendioxy)bis(ethylamine), often used as linker in the synthesis of bioconjugates), was introduced at position 7 of the indolizine ring. As drawn in Scheme 2C, isonicotinic amide $\mathbf{1 4}$ was prepared from the activated ester $13^{22}$ and mono-Boc-protected 2,2'(ethylendioxy)bis(ethylamine). Alkylation with the ethyl 2bromoacetate gave the pyridinium salt $15 \mathrm{a}$. To highlight the high reactivity of ester at position 1 of pyridinium salts, due to the presence of the positive charge at $\beta$-position, a transesterification was realized in $\mathrm{CD}_{3} \mathrm{OD}$ at room temperature (rt) with the formation of the deuterated analogue $15 \mathrm{~b}$. The deuterated indolizine $\mathbf{1 6}$ was then obtained by cyclization of $\mathbf{1 5 b}$ with the reactive propiolate 5 as described above. We thus formed a reactive scaffold containing two esters of different 
Scheme 2. Different Strategies of Formation and Modulation of Tripodal Core. Amine Containing Reactants were Introduced at Positions 1 (Part A), 3 (Part B) or 7 (Part C) of the Indolizine Ring

A
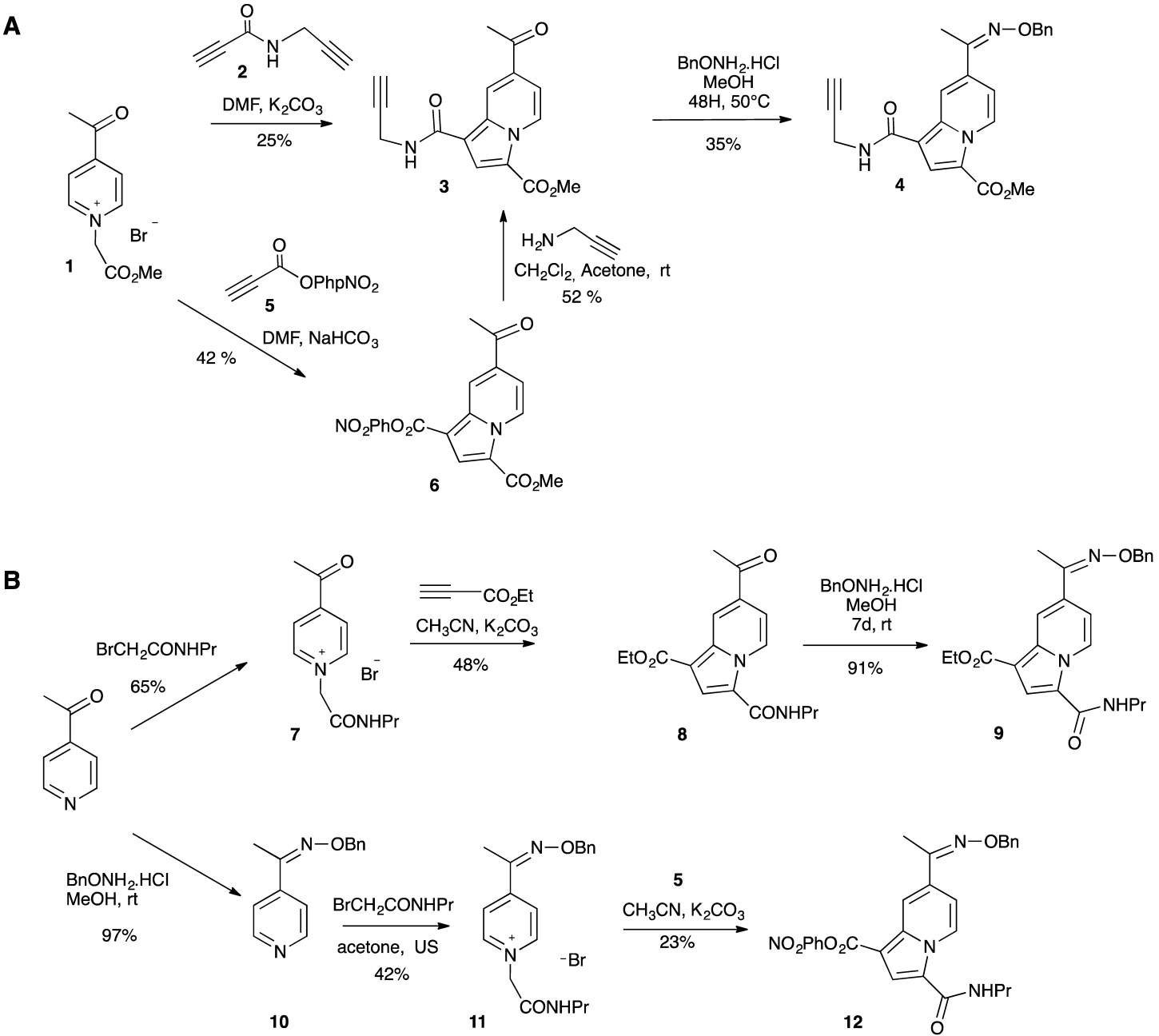

C

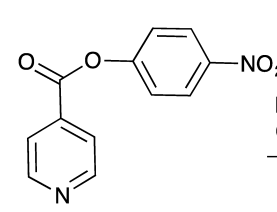

13

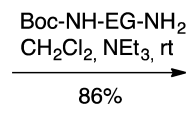

$\curvearrowright \mathrm{O} \sim \mathrm{NH} \equiv \mathrm{NH}-\mathrm{OH}-\mathrm{NH}$

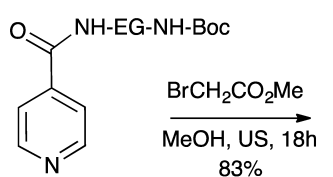

14
$83 \%$

$\mathrm{CD}_{3} \mathrm{OD}$

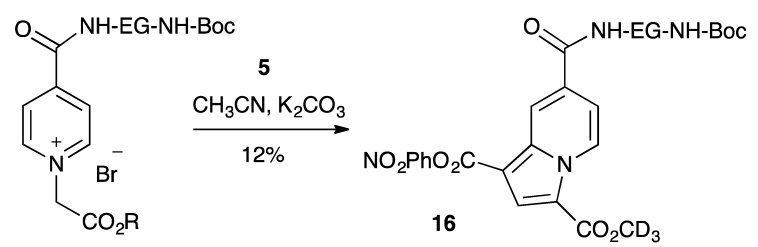

stabilities, and a Boc-protected amine that can easily be released by trifluoroacetic acid (TFA) treatment.

The latter approach was chosen to prepare the two biotintagged COB223 and COB236. Indeed, direct binding of biotin to the molecule was precluded due to limited access of the drug by the target protein during affinity chromatography, and to overcome this problem, ethylene glycol (EG) linker such as in Biot-NH-EG-NH $\mathrm{NH}_{2}$ (Scheme 3) was added. The site of functionalization of the active drug by the biotin was another key point to examine. As reported earlier, ${ }^{19}$ the structureactivity relationships pointed to the importance of both the dansyl chromophore and the polyamine linker for the antiangiogenic properties. We therefore chose to modify the Boc group of COB223 and COB236. As depicted in Scheme 3, the drugs were introduced at the last step to limit tedious purification steps. The key intermediate, Biot-NH-EG-NH-Py 18, was prepared from Biot-NH-EG- $\mathrm{NH}_{2} 17^{23}$ by reaction with the reactive para-nitrophenyl isonicotinic ester 13. Alkylation with methyl 2-bromoacetate in acetone gave the corresponding pyridinium bromide 19 in excellent yield. This intermediate was stable at room temperature for extended period of time. Cyclization with para-nitrophenyl propiolate $\mathbf{5}$ in dimethylformamide (DMF) in the presence of $\mathrm{K}_{2} \mathrm{CO}_{3}$ gave the indolizine 20 in reasonable yield. Due to the reactivity of the paranitrophenyl ester, the next step was performed without further purification. The nucleophilic substitution by the primary amines of $\mathbf{2 1 a}, \mathbf{b}$, issued from the Boc deprotection of COB223 
Scheme 3. Synthetic Pathway for the Biotin-Tagged Compounds<smiles>NC(=O)NC(=O)CCCCC1SCC2NC(=O)NC21</smiles><smiles>O=C(CCCCC1SCC2NC(=O)NC21)NCCOCCOCCNC(=O)c1ccncc1</smiles>

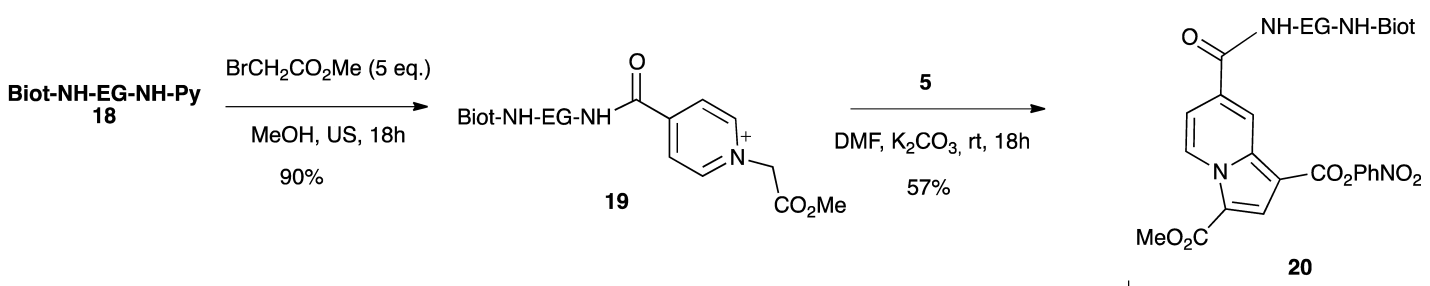<smiles>Cc1ccc(C(=O)OCc2ccc(C(C)(C)C)cc2)cc1</smiles>

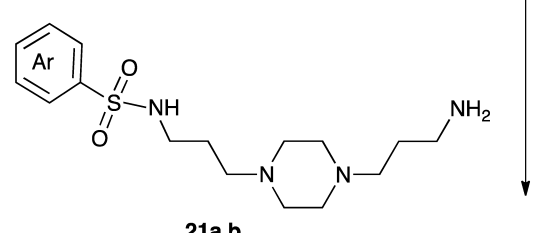

COB223-biotin

COB236-biotin

or COB236, yielded the corresponding biotin-tagged molecules.

COB223-biotin and COB236-biotin were then immobilized onto streptavidin agarose beads. We had observed during the synthesis that COB223-biotin and COB236-biotin were very stable in organic solvents, and to test the stability in aqueous solutions, the samples of the modified gels were suspended in a $\mathrm{pH} 7.5$ buffer that was then used for affinity chromatography. The suspensions were shaken several days at various temperatures $\left(40-70{ }^{\circ} \mathrm{C}\right)$. Thanks to the fluorescence properties of the indolizine core, the gels and supernatants obtained after centrifugation were easily analyzed under UV-vis irradiation. The gels remained highly fluorescent, and no detectable trace of fluorescent molecules was observed in the supernatants (see Figure S1), confirming the stability of COB-biotinstreptavidin columns in conditions much harsher than those routinely used in biology.

As COB223 was previously shown to be antiangiogenic, whereas the structurally related COB236 was inactive in angiogenesis assays, we selected a highly vascularized tissue, the placenta, as a source of target proteins. Affinity purifications of COB-binding proteins were then performed by loading $400 \mathrm{mg}$ of placental extract proteins (in Tris $20 \mathrm{mM}-\mathrm{HCl} \mathrm{pH} 7.5, \mathrm{NaCl}$ $75 \mathrm{mM}$, Triton X-100 0.05\%) onto each column. Experiments were performed at $4{ }^{\circ} \mathrm{C}$ in the presence of protease inhibitors (Sigma) to prevent any degradation not only of the proteins but also of the drug-biotin conjugates. The columns were washed with 5 volumes of Tris $20 \mathrm{mM}-\mathrm{HCl} \mathrm{pH} 7.5$ and then eluted successively with 3 column volumes of Tris $20 \mathrm{mM}-\mathrm{HCl}$ $\mathrm{pH} 7.50 .2 \mathrm{M} \mathrm{NaCl}$ and then with 3 column volumes of Tris 20 $\mathrm{mM}-\mathrm{HCl} \mathrm{pH} 7.5,0.5 \mathrm{M} \mathrm{NaCl}$. The $0.5 \mathrm{M} \mathrm{NaCl}$ eluates of each column were concentrated by sodium dodecyl sulfate polyacrylamide gel electrophoresis (SDS-PAGE) in stacking polyacrylamide gels, which were then trypsinized and the released peptides were analyzed by liquid chromatographytandem mass spectrometry (LC-MS/MS). This allowed us to identify 40 proteins that were significantly more abundant in COB223-agarose eluates than in COB236-agarose eluates (Table S1). Although we previously reported that COB223 inhibits VEGF receptor 2 (VEGFR2) activation of ERK1/2 phosphorylation in microvascular endothelial cells, ${ }^{19}$ none of these COB223-binding proteins was a known intermediate of the VEGF signaling pathway. Then, using the DAVID Bioinformatics Resource (v 6.8; NIAID, NIH), we searched to which pathway these proteins belonged in majority. It appeared that 13 out of 38 members ( 2 out of 40 were not referenced in DAVID) of this protein cluster (listed in Table 1)

Table 1. Proteins Differentially Bound to COB223-BiotinAvidin-Agarose vs COB236-Biotin-Avidin-Agarose and Recognized as Poly(A)-RNA Binding Proteins under Molecular Function Ontology Analysis ${ }^{a}$

\begin{tabular}{lll}
$\begin{array}{c}\text { COB223/COB236 } \\
\text { enrichment fold }\end{array}$ & \multicolumn{1}{c}{ protein name } & gene symbol \\
17 & $\begin{array}{l}\text { proliferation-associated protein 2G4 } \\
\text { polypyrimidine tract-binding } \\
\text { protein 1 } \\
\text { heterogeneous nuclear } \\
\text { ribonucleoprotein M }\end{array}$ & PA2G4 \\
& PTBP1 \\
6 & protein lin-28 homolog B & HNRNPM \\
6 & ribonuclease 4 & LIN28B \\
5.5 & ubiquitin-conjugating enzyme E2N & UBE2N \\
5 & poly(rC)-binding protein 1 & $P C B P 1$ \\
5 & vigilin & $H D L B P$ \\
COB223 only & 40S ribosomal protein S20 & $R P S 20$ \\
COB223 only & RNA-binding protein Raly & $R A L Y$ \\
COB223 only & polyadenylate-binding protein 1 & $P A B P C 1$ \\
COB223 only & 40S ribosomal protein S14 & $R P S 14$ \\
COB223 only & single-stranded DNA-binding & $S S B P 1$ \\
COB223 only & protein, mitochondrial &
\end{tabular}

${ }^{a}$ The ratio of intensities (when detectable under both conditions) was determined from MS/MS analyses. 
were annotated as poly(A) RNA-binding proteins, corresponding to a 4.7 -fold enrichment $\left(p\right.$ value $=1.9 \times 10^{-5}$ corresponding to $2.0 \times 10^{-3}$ after Benjamini-Hochberg correction for multiple testing)..$^{24,25}$ The procedure, called gene ontology enrichment, searches for biological functions, processes, and localizations that are over-represented in the 38 "hit proteins" as compared to a random selection of 38 proteins among translated sequences from the whole human genome. ${ }^{26}$

Such a low $p$ value indicates a significant enrichment of poly(A) RNA-binding proteins among the proteins binding specifically to COB223. These included two ribosomal proteins (S14, S20) and several proteins known to regulate RNA translation, splicing, or stability through tight protein-RNA interactions. We thus speculate that COB223 might interfere with the RNA-processing machinery and thereby modify the level of expression of essential components of the VEGF signaling pathway. The most differentially retained RNAbinding protein, PA2G4, is of great interest, as it is also known as ErbB3-binding protein (EBP1). EBP1 has been implicated in growth inhibition and the induction of differentiation of human cancer cells. ${ }^{27,28}$ Whether it can also interact with VEGF receptors and the VEGF signaling pathway will be worth testing in the future.

\section{CONCLUSIONS}

As a conclusion, we have developed the chemistry of 1,3,7trifunctionalized indolizines toward their uses as di- or tripodal scaffolds. This approach has several advantages, and in particular commercially or easily accessible reactants and mild reaction conditions. Various functional groups (esters, amines, alkynes, oxyamines, carbonyls, etc.) were successfully introduced on the scaffold by combining pre- or postfunctionalization reactions, ensuring the versatility of this platform. Another interesting aspect is linked to the intrinsic fluorescence of the indolizine ring ${ }^{16,17,29,30}$ that allows the easy monitoring of the molecules not only during synthesis, but also in the course of biochemical and biological assays. In the present work, fluorescence properties were applied to assess the stability of biotin-tagged molecules.

To illustrate a first application as a tool in molecular biology, we created a new biotin-modified scaffold convenient to prepare biotin-tagged drugs for cellular targets identification using proteomics analysis. ${ }^{31}$ The biotin-derived indolizine 20 was synthesized in two steps, and was used as the key reactant to label amine-containing molecules. As proof of concept, the antiangiogenic COB223 drug and the inactive COB236 analogue were studied. The drug-selective discrimination of proteins observed after elution of the cell lysates through the affinity columns, functionalized either with the active (COB223) drug or its structurally related inactive (COB236) analogue, is a clear indication that the presence of the indolizine core does not limit the drug-protein interaction, thus confirming the usefulness of the new biotin-indolizine reagent for drug tagging.

Very interestingly, affinity purification of COB223-interacting proteins from human placental extracts allowed us to identify unanticipated protein targets. None of the primary signaling enzymes that contribute to the VEGFR2 signaling cascade (VEGF receptor 2, Ras, intracellular protein-kinases of the ERK, p38 MAP-kinase, and Akt families) ${ }^{32}$ was present among the affinity-purified proteins. In contrast, COB223 appeared to interact with several regulatory RNA-binding proteins, suggesting that it targets indirect mechanisms such as mRNA editing or mRNA stability, which in turn may affect the level of expression of some crucial components of the VEGFR2 signaling pathway. Another possibility is that COB223 acts via binding to PA2G4/EBP1 through direct interference with the VEGF receptors. These unexpected observations open the way for a whole set of new biological experiments aimed at better understanding the mechanism of action of the antiangiogenic compound COB223, but the exploration of these new hypotheses goes beyond the scope of the present publication mainly dedicated to the indolizine chemistry.

From the chemical point of view, we are now considering other applications in the fields of surface functionalization and macromolecules modifications.

\section{MATERIALS AND METHODS}

NMR spectra were recorded at room temperature in $5 \mathrm{~mm}$ tubes on a Bruker AC $400 \mathrm{MHz}$ spectrometer (NMR facility, PCN-ICMG, Grenoble). Chemical shifts $(\delta)$ are reported in parts per million (ppm) from low to high field and referenced to residual nondeuterated solvent relative to $\mathrm{Me}_{4} \mathrm{Si}$. Standard abbreviations for multiplicity were used as follows: $s$ = singlet; $d$ = doublet; $\mathrm{t}=$ triplet; $\mathrm{m}=$ multiplet. High-resolution mass spectrometry (HRMS) was carried out on a Bruker UHR-QTOF MaXis-ETD (time of flight) mass spectrometer using electrospray ionization (ESI) in Institut de Chimie Organique et Analytique (CBM-ICOA) in Orleans (France). Reversedphase HPLC was performed with a $\mu$-bondapak-C18 analytical column (Waters Corporation, Milford, MA). A Waters chromatographic system was used, with two M-510 pumps and a photodiode array detector Waters 996 using Millenium 32 software. A linear gradient from 0 to $100 \%$ methanol in $\mathrm{H}_{2} \mathrm{O}$ pH 2.5 (phosphoric acid), $2 \mathrm{~mL} / \mathrm{min}$ flow rate, was used.

$N$-(Prop-2-yn-1-yl)prop-2-ynamide 2 was prepared by biocatalyzed reaction as reported by us. ${ }^{20}$ para-Nitrophenyl propiolate 5, ${ }^{33}$ para-nitrophenyl isonicotinate $13,{ }^{22} \mathrm{NH}_{2} \mathrm{EG}$ Biotine.TFA 21, ${ }^{34}$ and dansyl and tosyl sulfonamides 21a,b were prepared following reported procedures. ${ }^{19}$ Streptavidinagarose was purchased from Thermo Scientific Pierce (Waltham, MA).

Syntheses. 7-Acetyl-3-methyl-1-[(prop-2-yn-1-yl)carbamoyl]indolizine-3-carboxylate 3. Method 1. The 4acetylpyridinium bromide $1(113 \mathrm{mg}, 0.41 \mathrm{mmol})$ and propiolic amide 2 (53 mg, $0.49 \mathrm{mmol})$ were dissolved in DMF $(2 \mathrm{~mL})$. $\mathrm{K}_{2} \mathrm{CO}_{3}(57 \mathrm{mg}, 0.41 \mathrm{mmol}$ ) was then added and the mixture was stirred overnight at rt. The solid was filtered off and the solution concentrated under reduced pressure. The residue was then purified by flash chromatography on silica gel (cyclohexane/ethyl acetate: 6/4). Indolizine 3 was thus isolated as a yellow solid (30 mg, 25\%).

Method 2. A suspension of propargylamine $(64 \mu \mathrm{L}, 1 \mathrm{mmol})$ and indolizine $6(60 \mathrm{mg}, 0.16 \mathrm{mmol})$ in $\mathrm{CH}_{2} \mathrm{Cl}_{2}(3 \mathrm{~mL})$ was vigorously stirred during 3 days at $\mathrm{rt}$. The solid was filtered off and the solution concentrated under reduced pressure. The residue was then purified by flash chromatography on silica gel (cyclohexane/ethyl acetate: 6/4). Indolizine 3 was thus isolated as a yellow solid ( $24 \mathrm{mg}, 52 \%$ ).

mp: $228-229{ }^{\circ} \mathrm{C} ;{ }^{1} \mathrm{H}$ NMR $\left(400 \mathrm{MHz}, \mathrm{CDCl}_{3}\right) \delta 9.48(\mathrm{dd}$, $1 \mathrm{H}, J=7.4,0.9 \mathrm{~Hz}), 9.17(\mathrm{dd}, 1 \mathrm{H}, J=1.9,0.9 \mathrm{~Hz}), 7.79(\mathrm{~s}$, $1 \mathrm{H}), 7.58(\mathrm{dd}, 1 \mathrm{H}, J=7.4,1.9 \mathrm{~Hz}), 6.22(\mathrm{br} \mathrm{m}, 1 \mathrm{H}), 4.34(\mathrm{dd}$, $2 \mathrm{H}, J=5.3,2.5 \mathrm{~Hz}), 4.00(\mathrm{~s}, 3 \mathrm{H}), 2.74(\mathrm{~s}, 3 \mathrm{H}), 2.36(\mathrm{t}, 1 \mathrm{H}, J=$ $2.5 \mathrm{~Hz}) ;{ }^{13} \mathrm{C} \mathrm{NMR}\left(100 \mathrm{MHz}, \mathrm{CDCl}_{3}\right) \delta 196.1,163.3,160.9$, 137.1, 132.5, 127.1, 122.3, 120.1, 115.9, 111.9, 110.9, 79.6, 71.9, 
$51.8,29.3,26.1$; HRMS (ESI) $m / z$ : calcd for $\mathrm{C}_{16} \mathrm{H}_{15} \mathrm{~N}_{2} \mathrm{O}_{4}[\mathrm{M}+$ $\mathrm{H}]^{+}$299.1026, obsd 299.1031.

7-[(1-(Benzyloxy)imino)ethyl]-3-methyl-1-[(prop-2-yn-1yl)carbamoyl]indolizine-3-carboxylate 4. A suspension of indolizine 3 (30 $\mathrm{mg}, 0.10 \mathrm{mmol}$ ) and $O$-benzylhydroxylamine hydrochloride $(50 \mathrm{mg}, 0.31 \mathrm{mmol})$ was stirred in $\mathrm{MeOH}$ (1 $\mathrm{mL}$ ) for $48 \mathrm{~h}$ at $50{ }^{\circ} \mathrm{C}$. The solution was then kept at $0{ }^{\circ} \mathrm{C}$ overnight and the white precipitate was filtered off and dried. The oxime ether 4 was obtained in $35 \%$ yield $(14 \mathrm{mg}, 0.03$ mmol). mp: $169-170{ }^{\circ} \mathrm{C}$; ${ }^{1} \mathrm{H}$ NMR (400 MHz, $\left.\mathrm{CDCl}_{3}\right) \delta 9.38$ (dd, $1 \mathrm{H}, J=7.4,0.9 \mathrm{~Hz}), 8.71(\mathrm{~m}, 1 \mathrm{H}), 7.71(\mathrm{~s}, 1 \mathrm{H}), 7.60(\mathrm{dd}$, $1 \mathrm{H}, J=7.4,1.9 \mathrm{~Hz}), 7.3-7.5(\mathrm{~m}, 5 \mathrm{H}), 6.13$ (br m, 1H), 5.33 (s, $2 \mathrm{H}), 4.32(\mathrm{dd}, 2 \mathrm{H}, J=5.3,2.5 \mathrm{~Hz}), 3.98(\mathrm{~s}, 3 \mathrm{H}), 2.38(\mathrm{~s}, 3 \mathrm{H})$, $2.36(\mathrm{t}, 1 \mathrm{H}, J=2.4 \mathrm{~Hz}) ;{ }^{13} \mathrm{C} \mathrm{NMR}\left(100 \mathrm{MHz}, \mathrm{CDCl}_{3}\right) \delta 163.7$, $161.2,152.7,138.4,137.7,133.4,128.2,127.9,126.6,119.7$, 117.3, 114.5, 111.8, 79.8, 77.9, 71.7, 51.5, 29.2, 11.6; HRMS (ESI) $m / z$ : calcd for $\mathrm{C}_{23} \mathrm{H}_{21} \mathrm{~N}_{3} \mathrm{NaO}_{4}[\mathrm{M}+\mathrm{Na}]^{+}$426.1424, obsd 426.1423; calcd for $\mathrm{C}_{23} \mathrm{H}_{22} \mathrm{~N}_{3} \mathrm{O}_{4}[\mathrm{M}+\mathrm{H}]^{+}$404.1605, obsd 404.1608 .

7-Acetyl-1-(4-nitrophenyl)-3-methyl-indolizine-1,3-dicarboxylate 6 . The 4-acetylpyridinium bromide 1 ( $128 \mathrm{mg}, 0.46$ $\mathrm{mmol}$ ) and para-nitrophenyl propiolic ester 5 (134 mg, 0.7 $\mathrm{mmol})$ were dissolved in DMF $(1.5 \mathrm{~mL}) . \mathrm{NaHCO}_{3}(39 \mathrm{mg}$, $0.46 \mathrm{mmol}$ ) was then added and the mixture was stirred overnight at rt. The solution was then diluted with $\mathrm{CH}_{2} \mathrm{Cl}_{2}$ (5 $\mathrm{mL})$ and the white solid $(\mathrm{NaBr})$ was filtered off. Diethyl ether $(10 \mathrm{~mL})$ was then added to the cloudy filtrate allowing the precipitation of a light suspension that was filtered off. The resulting clear solution was concentrated under reduced pressure and poured into a large volume of diethyl ether (50 $\mathrm{mL}$ ). The solution was allowed to stand at $\mathrm{rt}$ for $48 \mathrm{~h}$. The resulting precipitate was filtered, washed twice with diethyl ether and dried. Indolizine 6 was thus obtained as a beige solid (74 mg, 42\%). ${ }^{1} \mathrm{H}$ NMR (400 MHz, $\mathrm{CDCl}_{3}$ ) $\delta 9.64$ (dd, $1 \mathrm{H}, J$ $=7.2,0.8 \mathrm{~Hz}), 8.97(\mathrm{dd}, 1 \mathrm{H}, J=1.6,0.8 \mathrm{~Hz}), 8.40(\mathrm{~d}, 2 \mathrm{H}, J=$ $9.2 \mathrm{~Hz}), 8.24(\mathrm{~s}, 1 \mathrm{H}), 7.67(\mathrm{dd}, 2 \mathrm{H}, J=7.2,2.0 \mathrm{~Hz}), 7.52(\mathrm{~d}$, $1 \mathrm{H}, J=9.2 \mathrm{~Hz}), 4.04(\mathrm{~s}, 3 \mathrm{H}), 2.75(\mathrm{~s}, 3 \mathrm{H}) ;{ }^{13} \mathrm{C} \mathrm{NMR}(100$ $\left.\mathrm{MHz}, \mathrm{CDCl}_{3}\right) \delta 195.7,161.0$ (2C), 155.5, 145.4, 138.5, 133.8, 128.1, 125.3, 125.2, 122.7, 120.8, 117.1, 112.6, 106.3, 52.0, 26.2; HRMS (ESI) $m / z$ : calcd for $\mathrm{C}_{19} \mathrm{H}_{15} \mathrm{~N}_{2} \mathrm{O}_{7}[\mathrm{M}+\mathrm{H}]^{+} 383.0874$, obsd 383.0872 and calcd for $\mathrm{C}_{13} \mathrm{H}_{10} \mathrm{NO}_{4}\left[\mathrm{M}-\mathrm{OPhNO}_{2}\right]^{+}$ 244.0604, obsd 244.0605.

4-Acetyl-1-[(N-propylcarbamoyl)methyl]pyridinium Bromide 7. A mixture of 4-acetylpyridine $(158 \mu \mathrm{L}, 1.43 \mathrm{mmol})$ and 2-bromo- $\mathrm{N}$-propylacetamide (309 $\mathrm{mg}, 1.7 \mathrm{mmol}$ ) in acetone $(5 \mathrm{~mL})$ is stirred overnight under ultrasonic agitation. A large volume of diethyl ether was then added and the resulting mixture was vigorously stirred. The orange oil was separated, washed three times with diethyl ether, and dried under reduced pressure. The pyridinium salt 7 was thus isolated as a hygroscopic orange solid (279 $\mathrm{mg}, 65 \%) .{ }^{1} \mathrm{H}$ NMR (400 $\left.\mathrm{MHz}, \mathrm{DMSO}-d_{6}\right) \delta 9.21(\mathrm{~d}, 2 \mathrm{H}, J=7.0 \mathrm{~Hz}), 8.53(\mathrm{~d}, 2 \mathrm{H}, J=$ $7.0 \mathrm{~Hz}), 5.57(\mathrm{~s}, 2 \mathrm{H}), 3.12(\mathrm{dd}, 2 \mathrm{H}, J=12.8,7.2 \mathrm{~Hz}), 2.77(\mathrm{~s}$, $3 \mathrm{H}), 1.49(\mathrm{~m}, 2 \mathrm{H}), 0.90(\mathrm{t}, 3 \mathrm{H}, J=7.6 \mathrm{~Hz}) ;{ }^{13} \mathrm{C} \mathrm{NMR}(100$ MHz, DMSO- $\left.d_{6}\right) \delta 195.6,163.8,148.7,147.7,125.3,61.6,40.9$, 27.4, 22.1, 11.4; HRMS (ESI) $m / z$ : calcd for $\mathrm{C}_{12} \mathrm{H}_{17} \mathrm{~N}_{2} \mathrm{O}_{2}[\mathrm{M}]^{+}$ 221.1284, obsd 221.1285 and calcd for $\mathrm{C}_{13} \mathrm{H}_{21} \mathrm{~N}_{2} \mathrm{O}_{3}[\mathrm{M}+$ $\mathrm{MeOH}]^{+}$253.1547, obsd 253.1547.

7-Acetyl-1-ethyl-3-(N-propylcarbamoyl)indolizine-1-carboxylate 8 . The 4-acetylpyridinium bromide $7(121 \mathrm{mg}, 0.4$ $\mathrm{mmol})$ and ethyl propiolate $(45 \mu \mathrm{L}, 0.44 \mathrm{mmol})$ were dissolved in $\mathrm{CH}_{3} \mathrm{CN}(5 \mathrm{~mL}) . \mathrm{K}_{2} \mathrm{CO}_{3}(56 \mathrm{mg}, 0.4 \mathrm{mmol})$ was then added and the mixture was stirred overnight at rt. The solid was filtered off and the solution concentrated under reduced pressure. The resulting clear solution was concentrated under reduced pressure. The residue was then purified by flash chromatography on silica gel (cyclohexane/ethyl acetate: 7/3). Indolizine 8 was thus isolated as a yellow solid (60 mg, $48 \%$ ). ${ }^{1} \mathrm{H} \mathrm{NMR}\left(400 \mathrm{MHz}, \mathrm{CDCl}_{3}\right) \delta 9.59(\mathrm{dd}, 1 \mathrm{H}, J=7.6,0.8 \mathrm{~Hz})$, $8.81(\mathrm{dd}, 1 \mathrm{H}, J=2.0,0.8 \mathrm{~Hz}), 7.60(\mathrm{~s}, 1 \mathrm{H}), 7.38(\mathrm{dd}, 2 \mathrm{H}, J=$ 7.6, $2.0 \mathrm{~Hz}), 5.98$ (br s, $1 \mathrm{H}), 4.55(\mathrm{q}, 2 \mathrm{H}, J=7.2 \mathrm{~Hz}), 3.37(\mathrm{~m}$, $2 \mathrm{H}), 2.61(\mathrm{~s}, 3 \mathrm{H}), 1.61(\mathrm{~m}, 2 \mathrm{H}), 1.39(\mathrm{t}, 3 \mathrm{H}, J=7.2 \mathrm{~Hz}), 0.95$ $(\mathrm{t}, 3 \mathrm{H}, J=7.2 \mathrm{~Hz}) ;{ }^{13} \mathrm{C} \mathrm{NMR}\left(100 \mathrm{MHz}, \mathrm{CDCl}_{3}\right) \delta 196.1$, $163.9,161.1,136.3,132.1,127.9,121.3,119.6,119.0,111.1$, 108.1, 60.4, 41.3, 26.0, 23.1, 14.5, 11.5; HRMS (ESI) $m / z$ : calcd for $\mathrm{C}_{17} \mathrm{H}_{20} \mathrm{~N}_{2} \mathrm{NaO}_{4}[\mathrm{M}+\mathrm{Na}]^{+}$339.1315, obsd 339.1314; calcd for $\mathrm{C}_{17} \mathrm{H}_{21} \mathrm{~N}_{2} \mathrm{O}_{4}[\mathrm{M}+\mathrm{H}]^{+} 317.1496$, obsd 317.1494 and calcd for $\mathrm{C}_{14} \mathrm{H}_{12} \mathrm{NO}_{4}[\mathrm{M}-\mathrm{NHPr}]^{+}$258.0761, obsd 258.0762.

7-[(1-(Benzyloxy)imino)ethyl]-1-ethyl-3-(Npropylcarbamoyl)indolizine-1-carboxylate 9. A suspension of indolizine $8(23 \mathrm{mg}, 0.07 \mathrm{mmol})$ and $O$-benzylhydroxylamine hydrochloride (14 mg, $0.09 \mathrm{mmol}$ ) was stirred in $\mathrm{MeOH}$ (3 $\mathrm{mL}$ ) for 5 days at rt. The solution was diluted with $10 \mathrm{~mL}$ of water and extracted with $\mathrm{CH}_{2} \mathrm{Cl}_{2}(3 \times 10 \mathrm{~mL})$. Then, the organic phase was washed with brine $(10 \mathrm{~mL})$, dried over $\mathrm{MgSO}_{4}$, filtrated, and concentrated under vacuum. The oxime ether 9 was thus isolated as a yellow solid $(28 \mathrm{mg}, 91 \%) .{ }^{1} \mathrm{H}$ NMR $\left(400 \mathrm{MHz}, \mathrm{CDCl}_{3}\right) \delta 9.43(\mathrm{dd}, 1 \mathrm{H}, J=7.6,0.8 \mathrm{~Hz}), 8.81$ (dd, $1 \mathrm{H}, J=2.0,0.8 \mathrm{~Hz}), 7.56(\mathrm{~s}, 1 \mathrm{H}), 7.18-7.36(\mathrm{~m}, 6 \mathrm{H})$, 6.07 (br s, $1 \mathrm{H}), 5.20(2 \mathrm{H}, \mathrm{s}), 4.29(\mathrm{q}, 2 \mathrm{H}, J=7.2 \mathrm{~Hz}), 3.33(\mathrm{~m}$, $2 \mathrm{H}), 2.21(\mathrm{~s}, 3 \mathrm{H}), 1.57(\mathrm{~m}, 2 \mathrm{H}), 1.33(\mathrm{t}, 3 \mathrm{H}, J=7.2 \mathrm{~Hz}), 0.92$ $(\mathrm{t}, 3 \mathrm{H}, J=7.2 \mathrm{~Hz}) ;{ }^{13} \mathrm{C} \mathrm{NMR}\left(100 \mathrm{MHz}, \mathrm{CDCl}_{3}\right) \delta 164.3$, $161.4,152.7,137.7,133.0,128.5,128.3,128.0,127.4,118.4$, 118.3, 116.5, 111.0, 105.4, 76.7, 60.0, 41.2, 23.1, 14.6, 11.5; HRMS (ESI) $m / z$ : calcd for $\mathrm{C}_{24} \mathrm{H}_{27} \mathrm{~N}_{3} \mathrm{NaO}_{4}[\mathrm{M}+\mathrm{Na}]^{+}$ 444.1894, obsd 444.1892; calcd for $\mathrm{C}_{24} \mathrm{H}_{28} \mathrm{~N}_{3} \mathrm{O}_{4}[\mathrm{M}+\mathrm{H}]^{+}$ 422.2074, obsd 422.2072.

4-[(1-(Benzyloxy)imino)ethyl]pyridine 10. A suspension of 4-acetylpyridine $(443 \mu \mathrm{L}, 4 \mathrm{mmol})$ and $O$-benzylhydroxylamine hydrochloride $(640 \mathrm{mg}, 4 \mathrm{mmol})$ was stirred in $\mathrm{MeOH}(10$ $\mathrm{mL}$ ) for 3 days at rt. The solution was diluted with $30 \mathrm{~mL}$ of water and extracted with $\mathrm{CH}_{2} \mathrm{Cl}_{2}(3 \times 30 \mathrm{~mL})$. Then, the organic phase was washed with brine $(10 \mathrm{~mL})$, dried over $\mathrm{MgSO}_{4}$, filtrated, and concentrated under vacuum. The oxime ether 10 was thus isolated as a white amorphous solid $(878 \mathrm{mg}$, 97\%). ${ }^{1} \mathrm{H}$ NMR (400 MHz, $\left.\mathrm{CDCl}_{3}\right) \delta 8.67(\mathrm{~d}, 2 \mathrm{H}, J=6.4 \mathrm{~Hz})$, $7.69(\mathrm{~d}, 2 \mathrm{H}, J=6.4 \mathrm{~Hz}), 7.31-7.48(\mathrm{~m}, 5 \mathrm{H}), 5.34(2 \mathrm{H}, \mathrm{s}), 2.31$ $(\mathrm{s}, 3 \mathrm{H}) ;{ }^{13} \mathrm{C}$ NMR $\left(100 \mathrm{MHz}, \mathrm{CDCl}_{3}\right) \delta 152.2,148.3,145.5$, $137.3,128.5,128.4,128.3,128.1,128.0,120.7,77.1,12.0$; HRMS (ESI) $m / z$ : calcd for $\mathrm{C}_{14} \mathrm{H}_{15} \mathrm{~N}_{2} \mathrm{O}[\mathrm{M}+\mathrm{H}]^{+} 227.1179$, obsd 227.1183.

4-[(1-(Benzyloxy)imino)ethyl]-1-[(N-propylcarbamoyl)methyl]pyridinium Bromide 11. A mixture of pyridine 10 (227 $\mathrm{mg}, 1 \mathrm{mmol}$ ) and 2-bromo- $\mathrm{N}$-propylacetamide (361 mg, 1.2 $\mathrm{mmol})$ in $\mathrm{CH}_{2} \mathrm{Cl}_{2}(4 \mathrm{~mL})$ is stirred overnight under ultrasonic agitation. A large volume of diethyl ether was then added and the resulting mixture was vigorously stirred. The solid was filtered off, washed with acetone, and dried. The pyridinium salt 11 was thus isolated as a hygroscopic white solid $(165 \mathrm{mg}$, 42\%). ${ }^{1} \mathrm{H}$ NMR (400 MHz, CD 3 OD) $\delta 8.89$ (d, 2H, $J=6.8$ $\mathrm{Hz}), 8.37(\mathrm{~d}, 2 \mathrm{H}, J=6.8 \mathrm{~Hz}), 7.36-7.48(\mathrm{~m}, 5 \mathrm{H}), 5.47(\mathrm{~s}, 2 \mathrm{H})$, $5.43(\mathrm{~s}, 2 \mathrm{H}), 3.27(\mathrm{t}, 2 \mathrm{H}, J=7.2 \mathrm{~Hz}), 2.40(\mathrm{~s}, 3 \mathrm{H}), 1.62(\mathrm{~m}$, $2 \mathrm{H}), 1.00(\mathrm{t}, 3 \mathrm{H}, J=7.6 \mathrm{~Hz}) ;{ }^{13} \mathrm{C}$ NMR $\left(100 \mathrm{MHz}, \mathrm{CD}_{3} \mathrm{OD}\right) \delta$ $163.4,152.3,150.8,145.6,136.9,128.2,128.1,128.0,127.9$, 127.8, 123.1, 77.6, 61.0, 41.4, 22.0, 10.2; HRMS (ESI) $m / z$ : calcd for $\mathrm{C}_{19} \mathrm{H}_{24} \mathrm{~N}_{3} \mathrm{O}_{2}[\mathrm{M}]^{+} 326.1863$, obsd 326.1865 and calcd 
for $\mathrm{C}_{14} \mathrm{H}_{15} \mathrm{~N}_{2} \mathrm{O}\left[\mathrm{M}-\mathrm{CH}_{2} \mathrm{CONHPr}\right]^{+} m / z$ calcd 227.1179, obsd 227.1181.

7-[(1-(Benzyloxy)imino)ethyl]-1-(4-nitrophenyl)-3-(Npropylcarbamoyl)indolizine-1-carboxylate 12 . The pyridinium salt 11 (120 mg, $0.29 \mathrm{mmol})$ and para-nitrophenylpropiolic ester 5 ( $62 \mathrm{mg}, 0.32 \mathrm{mmol}$ ) were dissolved in $\mathrm{CH}_{3} \mathrm{CN}$ (3 $\mathrm{mL}) . \mathrm{K}_{2} \mathrm{CO}_{3}(42 \mathrm{mg}, 0.3 \mathrm{mmol}$ ) was then added and the mixture was stirred overnight at rt. The solid was filtered off and the solution concentrated under reduced pressure. The residue was then purified by flash chromatography on silica gel (cyclohexane/ethyl acetate: 7/3). Indolizine $\mathbf{1 2}$ was thus isolated as a yellow solid (34 mg, 23\%). ${ }^{1} \mathrm{H}$ NMR (400 $\left.\mathrm{MHz}, \mathrm{CDCl}_{3}\right) \delta 9.63(\mathrm{~d}, 1 \mathrm{H}, J=7.6 \mathrm{~Hz}), 8.44(\mathrm{~d}, 1 \mathrm{H}, J=1.2$ $\mathrm{Hz}), 8.81(\mathrm{~d}, 2 \mathrm{H}, J=9.2 \mathrm{~Hz}), 7.78(\mathrm{~s}, 1 \mathrm{H}), 7.57(\mathrm{dd}, 1 \mathrm{H}, J=$ 7.6, $2.0 \mathrm{~Hz}), 7.37-7.48(\mathrm{~m}, 7 \mathrm{H}), 6.27(\mathrm{br} \mathrm{s}, 1 \mathrm{H}), 5.34(2 \mathrm{H}, \mathrm{s})$, $4.50(\mathrm{q}, 2 \mathrm{H}, J=6.8 \mathrm{~Hz}), 2.33(\mathrm{~s}, 3 \mathrm{H}), 1.73(\mathrm{~m}, 2 \mathrm{H}), 1.07(\mathrm{t}$, $3 \mathrm{H}, J=7.2 \mathrm{~Hz}) ;{ }^{13} \mathrm{C} \mathrm{NMR}\left(100 \mathrm{MHz} \mathrm{CDCl}_{3}\right) \delta 161.3,161.1$, $155.8,152.4,145.1,139.0,137.6,134.5,128.5,128.3,128.0$, $127.9,125.3,122.7,119.1,118.6,116.0,111.8,102.7,76.9,41.3$, 23.1, 11.5; HRMS (ESI) $m / z$ : calcd for $\mathrm{C}_{28} \mathrm{H}_{27} \mathrm{~N}_{4} \mathrm{O}_{6}[\mathrm{M}+\mathrm{H}]^{+}$ 515.1924 , obsd 515.1925 and calcd for $\mathrm{C}_{22} \mathrm{H}_{22} \mathrm{~N}_{3} \mathrm{O}_{3}[\mathrm{M}-$ $\left.\mathrm{OPhNO}_{2}\right]^{+}$376.1656, obsd 376.1654.

N-[2-(2-(2-tert-Butyloxycarbonylaminoethoxy)ethoxy)ethyl]pyridine-4-carboxamide 14. A mixture of 2-(2-(2-tertbutyloxycarbonylaminoethoxy)ethoxy) ethylamine (407 $\mathrm{mg}$, $1.64 \mathrm{mmol})$, para-nitrophenyl isonicotinic ester $13(400 \mathrm{mg}$, $1.64 \mathrm{mmol})$ and $\mathrm{NEt}_{3}(0.22 \mu \mathrm{L}, 1.64 \mathrm{mmol})$ in $\mathrm{CH}_{2} \mathrm{Cl}_{2}(10$ $\mathrm{mL}$ ) was stirred overnight at $30{ }^{\circ} \mathrm{C}$. The mixture was then diluted with $\mathrm{CH}_{2} \mathrm{Cl}_{2}$ and washed twice with saturated aqueous $\mathrm{K}_{2} \mathrm{CO}_{3}(\mathrm{pH}>10)$ and twice with water and brine. The organic phase was dried over $\mathrm{MgSO}_{4}$ and evaporated under reduced pressure. Isonicotinamide $\mathbf{1 4}$ was thus isolated as a brown viscous oil (503 mg, 86\%). ${ }^{1} \mathrm{H}$ NMR (400 MHz, $\left.\mathrm{CD}_{3} \mathrm{OD}\right) \delta$ $8.68(\mathrm{dd}, 2 \mathrm{H}, J=4.4,1.6 \mathrm{~Hz}), 7.78(\mathrm{dd}, 2 \mathrm{H}, J=4.4,1.6 \mathrm{~Hz})$, $3.58-3.69(\mathrm{~m}, 8 \mathrm{H}), 3.50(\mathrm{t}, 2 \mathrm{H}, J=5.6 \mathrm{~Hz}), 3.20(\mathrm{t}, 2 \mathrm{H}, J=$ $5.2 \mathrm{~Hz}), 1.42(\mathrm{~s}, 9 \mathrm{H}) ;{ }^{13} \mathrm{C}$ NMR $\left(100 \mathrm{MHz}, \mathrm{CD}_{3} \mathrm{OD}\right) \delta 167.6$, 150.7, 143.6, 122.7, 71.1, 71.0, 70.9, 70.1, 40.8, 28.5; HRMS (ESI) $m / z$ : calcd for $\mathrm{C}_{17} \mathrm{H}_{27} \mathrm{~N}_{3} \mathrm{NaO}_{5}[\mathrm{M}+\mathrm{Na}]^{+} 376.1843$, obsd 376.1842; calcd for $\mathrm{C}_{17} \mathrm{H}_{28} \mathrm{~N}_{3} \mathrm{O}_{5}[\mathrm{M}+\mathrm{H}]^{+}$354.2023, obsd 354.2023 .

4-[(2-(2-(2-tert-Butyloxycarbonylaminoethoxy)ethoxy)ethyl)carbamoyl]-1-(2-methoxy-2-oxoethyl)pyridinium Bromide $15 a$ and 4-[(2-(2-(2-tert-Butyloxycarbonylaminoethoxy)ethoxy)ethyl)carbamoyl]-1-(2-tri-deuteromethoxy-2oxoethyl)pyridinium Bromide 15b. A mixture of isonicotinamide 14 (300 mg, $0.85 \mathrm{mmol})$ and methyl 2-bromoacetate $(0.2$ $\mathrm{mL}, 1.5 \mathrm{mmol})$ in acetone $(3 \mathrm{~mL})$ is stirred overnight under ultrasonic agitation. A large volume of diethyl ether was then added, and the resulting mixture was vigorously stirred. A dark oil was separated, washed three times with diethyl ether, and dried under reduced pressure. The pyridinium salt 15a was thus isolated as a brown oil $(362 \mathrm{mg}, 83 \%) .{ }^{1} \mathrm{H}$ NMR (400 MHz, $\left.\mathrm{CD}_{3} \mathrm{OD}\right) \delta 9.15(\mathrm{~d}, 2 \mathrm{H}, J=6.4 \mathrm{~Hz}), 8.51(\mathrm{~d}, 2 \mathrm{H}, J=6.4 \mathrm{~Hz})$, $5.70(\mathrm{~s}, 2 \mathrm{H}), 3.91(\mathrm{~s}, 3 \mathrm{H}), 3.74-3.67(\mathrm{~m}, 8 \mathrm{H}), 3.54(\mathrm{t}, 2 \mathrm{H}, J=$ $5.6 \mathrm{~Hz}), 3.23(\mathrm{t}, 2 \mathrm{H}, J=5.6 \mathrm{~Hz}), 1.46(\mathrm{~s}, 9 \mathrm{H}) ;{ }^{13} \mathrm{C}$ NMR $(100$ $\left.\mathrm{MHz}, \mathrm{CD}_{3} \mathrm{OD}\right) \delta 163.8,162.7,149.9,147.0,125.3,71.6,69.8$, 69.6, 68.6, 61.4, 40.0, 39.7, 28.5, 27.3; HRMS (ESI) $m / z$ : calcd for $\mathrm{C}_{20} \mathrm{H}_{32} \mathrm{~N}_{3} \mathrm{O}_{7}[\mathrm{M}]^{+} 426.2235$, obsd 426.2234.

$\mathrm{CD}_{3} \mathrm{O}$-ester $15 \mathbf{b}$ was obtained by dissolving $15 \mathbf{a}$ in $\mathrm{CD}_{3} \mathrm{OD}$. After one day of standing at $\mathrm{rt}$, the solution was evaporated to dryness. The $\mathrm{OCH}_{3} / \mathrm{OCD}_{3}$ exchange was confirmed by the loss of the ${ }^{1} \mathrm{H}$ and ${ }^{13} \mathrm{C}$ NMR signals.
7-[(2-(2-(2-tert-Butyloxycarbonylaminoethoxy)ethoxy)ethyl)carbamoyl]-1-(4-nitrophenyl)-3-(tri-deuteromethyl)-indolizine-1,3-dicarboxylate 16 . The pyridinium bromide $\mathbf{1 5 b}$ $(170 \mathrm{mg}, 0.33 \mathrm{mmol})$ and para-nitrophenyl propiolate 5 (71 $\mathrm{mg}, 0.33 \mathrm{mmol}$ ) were dissolved in acetonitrile $(10 \mathrm{~mL}) \cdot \mathrm{K}_{2} \mathrm{CO}_{3}$ (46 mg, $0.33 \mathrm{mmol}$ ) was then added and the solution stirred at rt for $6 \mathrm{~h}$. The mixture was filtered to remove insoluble salts, and the solvent was evaporated under reduced pressure. The residue was then triturated in $\mathrm{Et}_{2} \mathrm{O}$ and then filtered. The red solid part was stirred in $\mathrm{CH}_{2} \mathrm{Cl}_{2}$ and filtered again. The organic phase was evaporated to dryness to afford the indolizine $\mathbf{1 6}$ in good purity, as indicated by ${ }^{1} \mathrm{H}$ NMR. An analytically pure sample $(25 \mathrm{mg})$ was obtained by purification on $\mathrm{SiO}_{2}$ column with AcOEt/cyclohexane 8/2 (v/v) solvent mixture. ${ }^{1} \mathrm{H}$ NMR $\left(400 \mathrm{MHz}, \mathrm{CDCl}_{3}\right) \delta 9.52$ (br s, $\left.1 \mathrm{H}\right), 8.65$ (br s, $\left.1 \mathrm{H}\right), 8.25$ (d, $2 \mathrm{H}, J=9.2,2.4 \mathrm{~Hz}$ ), 8.09 (s, 1H), 7.49 (br s, $1 \mathrm{H}), 7.39$ (d, 2H, $J=8.8 \mathrm{~Hz}), 7.12$ (br s, $1 \mathrm{H}), 4.88($ br s, $1 \mathrm{H}), 3.70-3.50(\mathrm{~m}$, $8 \mathrm{H}), 3.47-3.45(\mathrm{~m}, 2 \mathrm{H}), 3.20-3.17(\mathrm{~m}, 2 \mathrm{H}), 1.32(\mathrm{~s}, 9 \mathrm{H}) ;{ }^{13} \mathrm{C}$ NMR $\left(100 \mathrm{MHz}, \mathrm{CDCl}_{3}\right) \delta 161.1,155.7,145.3,138.7,132.3$, 128.2, 125.2, 122.7, 117.5, 111.8, 113.7, 105.0, 70.2, 69.7, 51.9, 40.3, 40.2, 28.4; HRMS (ESI) $\mathrm{m} / z$ : calcd for $\mathrm{C}_{29} \mathrm{H}_{31} \mathrm{D}_{3} \mathrm{~N}_{4} \mathrm{NaO}_{11}[\mathrm{M}+\mathrm{Na}]^{+}$640.2310, obsd 640.2307; calcd for $\mathrm{C}_{29} \mathrm{H}_{32} \mathrm{D}_{3} \mathrm{~N}_{4} \mathrm{O}_{11}[\mathrm{M}+\mathrm{H}]^{+}$618.2481, obsd 618.2480.

Biotinylated-Isoniconitamide 18. A suspension of $\mathrm{NH}_{2} \mathrm{EG}-$ Biotine.TFA 17 (350 mg, $0.72 \mathrm{mmol}), \mathrm{NEt}_{3}(138 \mu \mathrm{L}, 1 \mathrm{mmol})$, and para-nitrophenyl isonicotinic ester $13(199 \mathrm{mg}, 0.80$ $\mathrm{mmol}$ ) in $\mathrm{CH}_{2} \mathrm{Cl}_{2}(5 \mathrm{~mL})$ was vigorously stirred overnight at rt. $\mathrm{Et}_{2} \mathrm{O}(10 \mathrm{~mL})$ was then added, and the resulting mixture was stirred for $15 \mathrm{~min}$. The white solid was filtered off, washed several times with $\mathrm{Et}_{2} \mathrm{O}$, and dried. Biotinylated-isonicotanimide 18 was thus isolated as a white powder $(296 \mathrm{mg}, 62 \%)$. ${ }^{1} \mathrm{H}$ NMR (400 MHz, CD $\left.3 \mathrm{OD}\right) \delta 8.73(\mathrm{dd}, 2 \mathrm{H}, J=4.8,2.4 \mathrm{~Hz}$ ), $7.83(\mathrm{dd}, 2 \mathrm{H}, J=4.8,2.4 \mathrm{~Hz}), 4.52(\mathrm{dd}, 1 \mathrm{H}, J=7.6,4.8 \mathrm{~Hz})$, $4.33(\mathrm{dd}, 1 \mathrm{H}, J=8.0,4.8 \mathrm{~Hz}), 3.74-3.64(\mathrm{~m}, 8 \mathrm{H}), 3.58(\mathrm{t}, 2 \mathrm{H}$, $J=5.6 \mathrm{~Hz}), 3.38(\mathrm{t}, 2 \mathrm{H}, J=5.6 \mathrm{~Hz}), 3.23(\mathrm{~m}, 1 \mathrm{H}), 2.96(\mathrm{dd}$, $1 \mathrm{H}, J=12.8,5.2 \mathrm{~Hz}), 2.73(\mathrm{~d}, 1 \mathrm{H}, J=12.8 \mathrm{~Hz}), 2.23(\mathrm{t}, 2 \mathrm{H}, J=$ $7.2 \mathrm{~Hz}), 1.78-1.61(\mathrm{~m}, 4 \mathrm{H}), 1.47(\mathrm{~m}, 2 \mathrm{H}) ;{ }^{13} \mathrm{C}$ NMR $(100$ $\left.\mathrm{MHz}, \mathrm{CD}_{3} \mathrm{OD}\right) \delta 174.6,166.3,164.6,149.5,142.4,121.5,69.8$, 69.7, 69.1, 68.8, 61.8, 60.1, 55.5, 39.5, 38.7, 35.2, 28.2, 28.0, 25.3; HRMS (ESI) $m / z$ : calcd for $\mathrm{C}_{22} \mathrm{H}_{33} \mathrm{~N}_{5} \mathrm{NaO}_{5} \mathrm{~S}[\mathrm{M}+\mathrm{Na}]^{+}$ 502.2095, obsd 502.2095; calcd for $\mathrm{C}_{22} \mathrm{H}_{34} \mathrm{~N}_{5} \mathrm{O}_{5} \mathrm{~S}[\mathrm{M}+\mathrm{H}]^{+}$ 480.2275, obsd 480.2276; calcd for $\mathrm{C}_{22} \mathrm{H}_{35} \mathrm{~N}_{5} \mathrm{O}_{5} \mathrm{~S}[\mathrm{M}+\mathrm{H}]^{2+}$ 240.6174 , obsd 240.6181 .

Biotinylated-Pyridinium Bromide 19. Biotinylated-isoniconitamide 18 (400 mg, $0.83 \mathrm{mmol}$ ) was dissolved in $\mathrm{MeOH}$ (15 $\mathrm{mL})$. Methyl bromoacetate $(0.41 \mathrm{~mL}, 4 \mathrm{mmol})$ was added, and the solution was stirred under microwave irradiation for 2 days. After evaporation of the solvent, the oily residue was stirred in acetone to eliminate the excess of reagent. The oil was separated and dried (472 $\mathrm{mg}, 0.74 \mathrm{mmol})$. The crude biotinylated-pyridinium bromide 19 was purified by slow crystallization from $\mathrm{MeOH} .{ }^{1} \mathrm{H}$ NMR $\left(400 \mathrm{MHz}, \mathrm{CD}_{3} \mathrm{OD}\right) \delta$ $9.13(\mathrm{~d}, 2 \mathrm{H}, J=6.4 \mathrm{~Hz}), 8.49(\mathrm{~d}, 2 \mathrm{H}, J=6.4 \mathrm{~Hz}), 5.70(\mathrm{~s}, 1 \mathrm{H})$, $4.48(\mathrm{~m}, 1 \mathrm{H}), 4.31(\mathrm{~m}, 1 \mathrm{H}), 3.87(\mathrm{~s}, 3 \mathrm{H}), 3.71-3.64(\mathrm{~m}, 8 \mathrm{H})$, $3.54(\mathrm{t}, 2 \mathrm{H}, J=5.6 \mathrm{~Hz}), 3.34(\mathrm{t}, 2 \mathrm{H}, J=5.6 \mathrm{~Hz}), 3.20(\mathrm{~m}, 1 \mathrm{H})$, $2.92(\mathrm{dd}, 1 \mathrm{H}, J=12.8,4.8 \mathrm{~Hz}), 2.69(\mathrm{~d}, 1 \mathrm{H}, J=12.4 \mathrm{~Hz}), 2.21$ $(\mathrm{t}, 2 \mathrm{H}, J=7.2 \mathrm{~Hz}), 1.78-1.51(\mathrm{~m}, 4 \mathrm{H}), 1.42(\mathrm{~m}, 2 \mathrm{H}) ;{ }^{13} \mathrm{C}$ NMR $\left(100 \mathrm{MHz}, \mathrm{CD}_{3} \mathrm{OD}\right) \delta 174.8,166.2,164.6,162.8,150.2$, $1471,125.7,69.9,69.8,69.1,68.6,61.9,60.2$, 55.6, 52.8, 40.0, 39.6, 38.8, 35.3, 28.3, 28.1, 25.4; HRMS (ESI) $\mathrm{m} / z$ : calcd for $\mathrm{C}_{25} \mathrm{H}_{38} \mathrm{~N}_{5} \mathrm{O}_{7} \mathrm{~S}[\mathrm{M}]^{+}$552.2486, obsd 552.2486; calcd for $\mathrm{C}_{25} \mathrm{H}_{39} \mathrm{~N}_{5} \mathrm{O}_{7} \mathrm{~S}[\mathrm{M}+\mathrm{H}]^{2+} 240.6174$, obsd 240.6180 . 
Biotinylated-Indolizine 20. Biotinylated-pyridinium bromide 19 (140 mg, $0.25 \mathrm{mmol})$ and para-nitrophenyl propiolate 5 (140 mg, $0.75 \mathrm{mmol}$ ) were dissolved in DMF $(1.5 \mathrm{~mL})$. $\mathrm{K}_{2} \mathrm{CO}_{3}$ (35 mg, $0.25 \mathrm{mmol}$ ) was then added and the solution was stirred at $\mathrm{rt}$ for $6 \mathrm{~h}$. A large volume of $\mathrm{Et}_{2} \mathrm{O}$ was added to the solution, and the resulting suspension was stirred for 15 min and then filtered. The red solid was stirred in $\mathrm{CH}_{2} \mathrm{Cl}_{2}$ and filtered. The organic phase was evaporated to dryness and used in the step without further purification. ${ }^{1} \mathrm{H}$ NMR $(400 \mathrm{MHz}$, $\left.\mathrm{CDCl}_{3}\right) \delta 9.49(\mathrm{~d}, 1 \mathrm{H}, J=7.2 \mathrm{~Hz}), 8.70($ br s, $1 \mathrm{H}), 8.25(\mathrm{~d}, 2 \mathrm{H}$, $J=9.2 \mathrm{~Hz}), 8.08$ (s, 1H), 7.79 (br s, $1 \mathrm{H}), 7.53$ (dd, $1 \mathrm{H}, J=7.2$, $2.0 \mathrm{~Hz}), 7.38(\mathrm{~d}, 2 \mathrm{H}, J=9.2 \mathrm{~Hz}), 6.44(\mathrm{br} \mathrm{s}, 1 \mathrm{H}), 6.18(\mathrm{~s}, 1 \mathrm{H})$, $5.32(\mathrm{~s}, 1 \mathrm{H}), 4.37(\mathrm{~m}, 1 \mathrm{H}), 4.18(\mathrm{~m}, 1 \mathrm{H}), 3.90(\mathrm{~s}, 3 \mathrm{H}), 3.69-$ $3.51(\mathrm{~m}, 8 \mathrm{H}), 3.49-3.45(\mathrm{~m}, 2 \mathrm{H}), 3.39-3.25(\mathrm{~m}, 2 \mathrm{H}), 3.10-$ $2.99(\mathrm{~m}, 1 \mathrm{H}), 2.78(\mathrm{dd}, 1 \mathrm{H}, J=13.2,5.2 \mathrm{~Hz}), 2.58(\mathrm{~d}, 1 \mathrm{H}, J=$ $12.8 \mathrm{~Hz}), 2.07(\mathrm{t}, 1 \mathrm{H}, J=7.6 \mathrm{~Hz}), 1.62-1.45(\mathrm{~m}, 4 \mathrm{H}), 1.30(\mathrm{~m}$, $2 \mathrm{H}) ;{ }^{13} \mathrm{C} \mathrm{NMR}\left(100 \mathrm{MHz}, \mathrm{CDCl}_{3}\right) \delta 172.2,164.2,162.8$, $160.1,160.0,154.6,144.2,137.7,131.3,127.1,124.2,121.7$, $115.3,112.9,103.8,69.1,69.0,68.8,68.7,60.7,59.1,54.3,52.4$, $50.9,39.4,39.2$, 38.0, 34.8, 26.9, 24.4; HRMS (ESI) $\mathrm{m} / z$ : calcd for $\mathrm{C}_{34} \mathrm{H}_{40} \mathrm{~N}_{6} \mathrm{NaO}_{11} \mathrm{~S}[\mathrm{M}+\mathrm{Na}]^{+}$763.2368, obsd 763.2371; calcd for $\mathrm{C}_{34} \mathrm{H}_{41} \mathrm{~N}_{6} \mathrm{O}_{11} \mathrm{~S}[\mathrm{M}+\mathrm{H}]^{+}$741.2549, obsd 741.2550; calcd for $\mathrm{C}_{34} \mathrm{H}_{42} \mathrm{~N}_{6} \mathrm{O}_{11} \mathrm{~S}[\mathrm{M}+2 \mathrm{H}]^{2+} 371.1311$, obsd 371.1318 .

Biotinylated-COB223. Biotinylated-indolizine 20 was dissolved in $\mathrm{CH}_{2} \mathrm{Cl}_{2}(2 \mathrm{~mL})$, and $\mathrm{N}$-dansyl-bis(aminopropyl)piperazine 21a (100 mg, $0.23 \mathrm{mmol}$ ) was added and the solution was stirred $72 \mathrm{~h}$ at rt. After evaporation of the solvent, the residue was dissolved in the minimum amount of $\mathrm{CH}_{2} \mathrm{Cl}_{2}$ and chromatographed onto $\mathrm{SiO}_{2}$ short column with AcOEt/ $\mathrm{MeOH} 5 / 5$ to $3 / 7(\mathrm{v} / \mathrm{v})$ solvent gradient. The desired compound corresponded to a fluorescent blue fraction that was evaporated to dryness. The residue was dissolved in $1 \mathrm{~mL}$ $\mathrm{MeOH}$ and $11 \mathrm{~N} \mathrm{HCl}$ (1 drop), acetone was added to separate the resulting salt that was obtained as an oil in $44 \%$ yield. ${ }^{1} \mathrm{H}$ NMR (400 MHz, CD 3 OD) $\delta 9.52$ (br s, $1 \mathrm{H}), 8.98$ (d, $1 \mathrm{H}, J=$ $8.8 \mathrm{~Hz}$ ), 8.96 (br s, $1 \mathrm{H}), 8.66$ (br s, $1 \mathrm{H}), 8.46(\mathrm{~d}, 1 \mathrm{H}, J=7.2$ $\mathrm{Hz}), 8.21(\mathrm{~d}, 1 \mathrm{H}, J=7.8 \mathrm{~Hz}), 8.11(\mathrm{~d}, 1 \mathrm{H}, J=5.2 \mathrm{~Hz}), 7.96(\mathrm{~m}$, $2 \mathrm{H}, J=9.2 \mathrm{~Hz}$ ), 7.47 (br s, $1 \mathrm{H}), 4.57$ (br s, $1 \mathrm{H}), 4.38$ (br s, $1 \mathrm{H}), 3.98(\mathrm{~s}, 3 \mathrm{H}), 3.79-3.65(\mathrm{~m}, 12 \mathrm{H}), 3.64-3.56(\mathrm{~m}, 4 \mathrm{H})$, $3.57(\mathrm{~s}, 6 \mathrm{H}), 3.45(\mathrm{~m}, 2 \mathrm{H}), 3.38(\mathrm{~m}, 2 \mathrm{H}), 3.22(\mathrm{~m}, 1 \mathrm{H}), 3.09$ $(\mathrm{m}, 1 \mathrm{H}), 2.96(\mathrm{dd}, 1 \mathrm{H}, J=12.9,5.0 \mathrm{~Hz}), 2.78(\mathrm{~d}, 1 \mathrm{H}, J=12.8$ $\mathrm{Hz}), 2.20(\mathrm{~m}, 4 \mathrm{H}), 2.04(\mathrm{~m}, 2 \mathrm{H}), 1.77-1.67(\mathrm{~m}, 1 \mathrm{H}), 1.66-$ $1.50(\mathrm{~m}, 3 \mathrm{H}), 1.45-1.35(\mathrm{~m}, 2 \mathrm{H})$; HRMS (ESI) $\mathrm{m} / z$ : calcd for $\mathrm{C}_{50} \mathrm{H}_{70} \mathrm{~N}_{10} \mathrm{NaO}_{10} \mathrm{~S}_{2}[\mathrm{M}+\mathrm{Na}]^{+}$1057.4610, obsd 1057.4611; calcd for $\mathrm{C}_{50} \mathrm{H}_{71} \mathrm{~N}_{10} \mathrm{O}_{10} \mathrm{~S}_{2}[\mathrm{M}+\mathrm{H}]^{+}$1035.4791, obsd 1035.4795; calcd for $\mathrm{C}_{50} \mathrm{H}_{72} \mathrm{~N}_{10} \mathrm{O}_{10} \mathrm{~S}_{2}[\mathrm{M}+2 \mathrm{H}]^{2+}$ 518.2431, obsd 518.2442.

Biotinylated-COB236. This compound was prepared as described for biotinylated-COB223 from biotinylated-indolizine 20 and $\mathrm{N}$-tosyl-bis(aminopropyl)piperazine $\mathbf{2 1 b} .{ }^{1} \mathrm{H}$ NMR $\left(400 \mathrm{MHz}, \mathrm{CD}_{3} \mathrm{OD}\right) \delta 9.51$ (dd, $\left.1 \mathrm{H}, J=7.4,0.9 \mathrm{~Hz}\right), 8.93(\mathrm{br}$ s, $1 \mathrm{H}), 8.05(\mathrm{~s}, 1 \mathrm{H}), 7.75(\mathrm{~d}, 2 \mathrm{H}, J=8.3 \mathrm{~Hz}), 7.45$ (dd, $1 \mathrm{H}, J=$ $7.4,2.0 \mathrm{~Hz}), 7.40(\mathrm{~d}, 1 \mathrm{H}, J=8.0 \mathrm{~Hz}), 4.50(\mathrm{dd}, 1 \mathrm{H}, \mathrm{dd}, 1 \mathrm{H}, J=$ 7.8, $4.4 \mathrm{~Hz}$ ), 4.30 (dd, $1 \mathrm{H}, \mathrm{dd}, 1 \mathrm{H}, J=7.8,4.4 \mathrm{~Hz}$ ), 3.97 (s, $3 \mathrm{H}), 3.78-3.63(\mathrm{~m}, 10 \mathrm{H}), 3.59(\mathrm{t}, 2 \mathrm{H}, J=5.4 \mathrm{~Hz}), 3.48(\mathrm{t}, 2 \mathrm{H}$, $J=6.8 \mathrm{~Hz}), 3.39(\mathrm{~s}, 3 \mathrm{H}), 3.38(\mathrm{~m}, 2 \mathrm{H}), 3.17(\mathrm{~m}, 1 \mathrm{H}), 2.96-$ $2.89(\mathrm{~m}, 2 \mathrm{H}), 2.72(\mathrm{~d}, 1 \mathrm{H}, J=12.7 \mathrm{~Hz}), 2.53(\mathrm{t}, 2 \mathrm{H}, J=7.1$ $\mathrm{Hz}), 2.39(\mathrm{t}, 2 \mathrm{H}, J=7.2 \mathrm{~Hz}), 2.18(\mathrm{t}, 2 \mathrm{H}, J=7.3 \mathrm{~Hz}), 1.87(\mathrm{~m}$, $2 \mathrm{H}), 1.77-1.51(\mathrm{~m}, 4 \mathrm{H}), 1.43-1.35(\mathrm{~m}, 2 \mathrm{H})$; HRMS (ESI) $\mathrm{m} /$ $z$ : calcd for $\mathrm{C}_{45} \mathrm{H}_{65} \mathrm{~N}_{9} \mathrm{NaO}_{10} \mathrm{~S}_{2}[\mathrm{M}+\mathrm{Na}]^{+}$978.4188, obsd 978.4193; calcd for $\mathrm{C}_{45} \mathrm{H}_{66} \mathrm{~N}_{9} \mathrm{O}_{10} \mathrm{~S}_{2}[\mathrm{M}+\mathrm{H}]^{+}$956.4367, obsd 956.4367; calcd for $\mathrm{C}_{45} \mathrm{H}_{67} \mathrm{~N}_{9} \mathrm{O}_{10} \mathrm{~S}_{2}[\mathrm{M}+2 \mathrm{H}]^{2+} 478.7221$, obsd 478.7230 .
Biological Procedures. Affinity Chromatography of COB223/236-Binding Proteins from Human Placenta. Samples $(0.2 \mathrm{mg})$ of biotinylated-COB223 or biotinylatedCOB236 were separately bound onto two $2 \mathrm{~mL}$ columns of strepavidin-agarose for $20 \mathrm{~min}$ at room temperature. The columns were then equilibrated in Tris $20 \mathrm{mM}-\mathrm{HCl}$ buffer $\mathrm{pH}$ 7.5. Human placental tissue was homogenized in Tris $20 \mathrm{mM}$ $\mathrm{HCl}$ buffer $\mathrm{pH} 7.5$ supplemented with $0.15 \mathrm{M} \mathrm{NaCl}$ and $0.1 \%$ Triton X-100, and the cytosolic extracts were prepared by centrifugation at $20000 \mathrm{~g}$. Fractions of $10 \mathrm{~mL}$ of placental cytosolic extracts (containing $35 \mathrm{mg}$ of proteins) were diluted twice in Tris $20 \mathrm{mM}-\mathrm{HCl}$ buffer $\mathrm{pH} 7.5$ and loaded onto each affinity column, which was then kept at $4{ }^{\circ} \mathrm{C}$. The filtrates were collected and the columns were sequentially washed with 10 $\mathrm{mL}$ of Tris buffer $0 \mathrm{M} \mathrm{NaCl}$ and $6 \mathrm{~mL}$ Tris buffer before elution using $0.2 \mathrm{M} \mathrm{NaCl}, 6 \mathrm{~mL}$ Tris buffer, $0.5 \mathrm{M} \mathrm{NaCl}$, and 6 $\mathrm{mL}$ Tris buffer and $1 \mathrm{M} \mathrm{NaCl}$. All of the steps were performed at $4{ }^{\circ} \mathrm{C}$ in the presence of protease inhibitors (Sigma). Proteins eluted with $0.2 \mathrm{M} \mathrm{NaCl}$ and $0.5 \mathrm{M} \mathrm{NaCl}$ were submitted to mass spectrometry-based analyses.

Mass Spectrometry-Based Proteomic Analyses. Protein preparation and mass spectrometry-based proteomic analyses were realized as previously described. ${ }^{35}$ Briefly, extracted proteins were stacked in the top of a SDS-PAGE gel (NuPAGE 4-12\%, Invitrogen) before in-gel digestion using trypsin (Promega, sequencing grade). Resulting peptides were analyzed by online nanoLC-MS/MS (UltiMate 3000 and LTQ-Orbitrap Velos Pro, Thermo Scientific) using a 120-min gradient. Peptides were identified through concomitant searches against the Uniprot databank (Homo sapiens taxonomy) and a classical contaminants database (in-house) and the corresponding reversed databases using Mascot (version 2.5). The Proline software (http://proline. profiproteomics.fr) was used to filter the results (conservation of rank 1 peptides, peptide identification FDR $<1 \%$ as calculated on peptide scores by employing the reverse database strategy, minimum peptide score of 25 , and minimum of 1 specific peptide per identified protein group) before performing a compilation, grouping, and comparison of the protein groups from the COB223 and COB236 samples. Proteins from the contaminants database and additional keratins were discarded from the final list of identified proteins. Proteins were considered as enriched in COB223 samples if they were identified only in these samples with a minimum of three weighted spectral counts or enriched at least five times in COB223 samples compared to COB236 ones.

\section{ASSOCIATED CONTENT}

\section{Supporting Information}

The Supporting Information is available free of charge on the ACS Publications website at DOI: 10.1021/acsomega.7b01184.

Chemical stability of the COB-biotin modified beads, NMR spectra and HPLC chromatograms, affinity chromatography and mass spectrometry-based proteomic analysis (PDF)

\section{AUTHOR INFORMATION}

\section{Corresponding Author}

*E-mail: martine.demeunynck@univ-grenoble-alpes.fr.

ORCID

Martine Demeunynck: 0000-0001-7096-8699 


\section{Notes}

The authors declare no competing financial interest.

\section{ACKNOWLEDGMENTS}

This research was supported by Labex ARCANE (ANR-11LABX-0003-01), Labex GRAL (Grenoble Alliance for Integrated Structural Cell Biology: ANR-10-LABX-49-01), AGIR research program of University Joseph Fourier, and the "Ligues Départementales contre le Cancer de l'Isère et de la Savoie". The proteomic analyses were partially supported by the Proteomics French Infrastructure ProFI (ANR-10-INBS-0801). The authors wish to acknowledge the support from the ICMG Chemistry Nanobio Platform, Grenoble, on which NMR work has been performed and from the bottom-up platform and informatics group of BGE/EDyP, which helped for proteomic analyses. Marvin was used as help for characterizing chemical structures, Marvin 6.0.2, 2012, ChemAxon (http://www.chemaxon.com).

\section{REFERENCES}

(1) Goldmann, A. S.; Glassner, M.; Inglis, A. J.; Barner-Kowollik, C. Post-Functionalization of Polymers via Orthogonal Ligation Chemistry. Macromol. Rapid Commun. 2013, 34, 810-849.

(2) McKay, C. S.; Finn, M. G. Click Chemistry in Complex Mixtures: Bioorthogonal Bioconjugation. Chem. Biol. 2014, 21, 1075-1101.

(3) Beal, D. M.; Albrow, V. E.; Burslem, G.; Hitchen, L.; Fernandes, C.; Lapthorn, C.; Roberts, L. R.; Selby, M. D.; Jones, L. H. Clickenabled heterotrifunctional template for sequential bioconjugations. Org. Biomol. Chem. 2012, 10, 548-554.

(4) Beal, D. M.; Jones, L. H. Molecular Scaffolds Using Multiple Orthogonal Conjugations: Applications in Chemical Biology and Drug Discovery. Angew. Chem., Int. Ed. 2012, 51, 6320-6326.

(5) Clavé, G.; Volland, H.; Flaender, M.; Gasparutto, D.; Romieu, A.; Renard, P.-Y. A universal and ready-to-use heterotrifunctional crosslinking reagent for facile synthetic access to sophisticated bioconjugates. Org. Biomol. Chem. 2010, 8, 4329-4345.

(6) Reddy, R. E.; Chen, Y.-Y.; Johnson, D. D.; Beligere, G. S.; Rege, S. D.; Pan, Y.; Thottathil, J. K. An efficient synthesis of a heterobifunctional coupling agent. Bioconjugate Chem. 2005, 16, $1323-1328$.

(7) Vaněk, V.; Pícha, J.; Fabre, B.; Buděšínský, M.; Lepšík, M.; Jiráček, J. The development of a versatile trifunctional scaffold for biological applications. Eur. J. Org. Chem. 2015, 2015, 3689-3701.

(8) Engelen, M.; Lombardi, A.; Vitale, R.; Lista, L.; Maglio, O.; Pavone, V.; Nastri, F. Branched porphyrins as functional scaffolds for multisite bioconjugation. Biotechnol. Appl. Biochem. 2015, 62, 383392.

(9) Baker, M. B.; Ghiviriga, I.; Castellano, R. K. Molecular multifunctionalization via electronically coupled lactones. Chem. Sci. 2012, 3, 1095-1099.

(10) Viault, G.; Dautrey, S.; Maindron, N.; Hardouin, J.; Renard, P.Y.; Romieu, A. The first "ready-to-use" benzene-based heterotrifunctional cross-linker for multiple bioconjugation. Org. Biomol. Chem. 2013, 11, 2693-2705.

(11) Bonte, S.; Ghinea, I. O.; Dinica, R.; Baussanne, I.; Demeunynck, $\mathrm{M}$. Investigation of the Pyridinium Ylide-Alkyne Cycloaddition as a Fluorogenic Coupling Reaction. Molecules 2016, 21, 332.

(12) Singh, G. S.; Mmatli, E. E. Recent progress in synthesis and bioactivity studies of indolizines. Eur. J. Med. Chem. 2011, 46, 52375257.

(13) Hodgkiss, R. J.; Middleton, R. W.; Parrick, J.; Rami, H. K.; Wardman, P.; Wilson, G. D. Bioreductive fluorescent markers for hypoxic cells: a study of 2-nitroimidazoles with 1-substituents containing fluorescent, bridgehead-nitrogen, bicyclic systems. J. Med. Chem. 1992, 35, 1920-1926.

(14) Kim, E.; Lee, Y.; Lee, S.; Park, S. B. Discovery, Understanding, and Bioapplication of Organic Fluorophore: A Case Study with an
Indolizine-Based Novel Fluorophore, Seoul-Fluor. Acc. Chem. Res. 2015, 48, 538-547.

(15) Marangoci, N.-L.; Popovici, L.; Ursu, E.-L.; Danac, R.; Clima, L.; Cojocaru, C.; Coroaba, A.; Neamtu, A.; Mangalagiu, I.; Pinteala, M.; Rotaru, A. Pyridyl-indolizine derivatives as DNA binders and $\mathrm{pH}$ sensitive fluorescent dyes. Tetrahedron 2016, 72, 8215-8222.

(16) Delattre, F.; Woisel, P.; Bria, M.; Surpateanu, G. Structural investigations of pyridin-4-yl indolizine modified $\beta$-cyclodextrin derivatives as fluorescent chemosensors for organic guest molecules. Carbohydr. Res. 2005, 340, 1706-1713.

(17) Becuwe, M.; Landy, D.; Delattre, F.; Cazier, F.; Fourmentin, S. Fluorescent Indolizine-b-Cyclodextrin Derivatives for the Detection of Volatile Organic Compounds. Sensors 2008, 8, 3689.

(18) Wu, X.; Cao, H.; Li, B.; Yin, G. The synthesis and fluorescence quenching properties of well soluble hybrid graphene material covalently functionalized with indolizine. Nanotechnology 2011, 22, No. 075202.

(19) Desroches-Castan, A.; Quélard, D.; Demeunynck, M.; Constant, J.-F.; Dong, C.; Keramidas, M.; Coll, J.-L.; Barette, C.; Lafanechère, L.; Feige, J.-J. A new chemical inhibitor of angiogenesis and tumorigenesis that targets the VEGF signaling pathway upstream of Ras. Oncotarget 2015, 6, 5382.

(20) Bonte, S.; Ghinea, I. O.; Baussanne, I.; Xuereb, J.-P.; Dinica, R.; Demeunynck, M. Investigation of the lipase-catalysed reaction of aliphatic amines with ethyl propiolate as a route to $\mathrm{N}$-substituted propiolamides. Tetrahedron 2013, 69, 5495-5500.

(21) Delattre, F.; Woisel, P.; Surpateanu, G.; Bria, M.; Cazier, F.; Decock, P. 1, 3-Dipolar cycloaddition reaction of bipyridinium ylides with the propynamido- $\beta$-cyclodextrin. A regiospecific synthesis of a new class of fluorescent $\beta$-cyclodextrins. Tetrahedron 2004, 60, 15571562.

(22) Christensen, J. B. A simple method for synthesis of active esters of isonicotinic and picolinic acids. Molecules 2001, 6, 47-51.

(23) Tokuhisa, H.; Liu, J.; Omori, K.; Kanesato, M.; Hiratani, K.; Baker, L. A. Efficient biosensor interfaces based on space-controlled self-assembled monolayers. Langmuir 2009, 25, 1633-1637.

(24) Benjamini, Y.; Hochberg, Y. Controlling the false discovery rate: a practical and powerful approach to multiple testing. J. R. Stat. Soc. B $1995,57,289-300$.

(25) Huang, D. W.; Sherman, B. T.; Lempicki, R. A. Systematic and integrative analysis of large gene lists using DAVID bioinformatics resources. Nat. Protoc. 2008, 4, 44-57.

(26) Rhee, S. Y.; Wood, V.; Dolinski, K.; Draghici, S. Use and misuse of the gene ontology annotations. Nat. Rev. Genet. 2008, 9, 509-515.

(27) Zhang, Y.; Linn, D.; Liu, Z.; Melamed, J.; Tavora, F.; Young, C. Y.; Burger, A. M.; Hamburger, A. W. EBP1, an ErbB3-binding protein, is decreased in prostate cancer and implicated in hormone resistance. Mol. Cancer Ther. 2008, 7, 3176-3186.

(28) Zhang, Y.; Akinmade, D.; Hamburger, A. W. Inhibition of heregulin mediated MCF-7 breast cancer cell growth by the ErbB3 binding protein EBP1. Cancer Lett. 2008, 265, 298-306.

(29) Troll, T.; Beckel, H.; Lentner-Böhm, C. Electrochemical synthesis of substituted indolizines; UV and fluorescence spectra. Tetrahedron 1997, 53, 81-90.

(30) Mahon, J.; Mehta, L.; Middleton, R.; Parrick, J.; Rami, H. Studies of some indolizine derivatives useful as fluorophores. J. Chem. Res., Synop. 1992, 11, 362-363.

(31) Wright, M.; Sieber, S. Chemical proteomics approaches for identifying the cellular targets of natural products. Nat. Prod. Rep. 2016, 33, 681-708.

(32) Simons, M.; Gordon, E.; Claesson-Welsh, L. Mechanisms and regulation of endothelial VEGF receptor signalling. Nat. Rev. Mol. Cell Biol. 2016, 17, 611-625.

(33) Delattre, F.; Woisel, P.; Surpateanu, G.; Cazier, F.; Blach, P. 1(4-Nitrophenoxycarbonyl)-7-pyridin-4-yl indolizine: A new versatile fluorescent building block. Application to the synthesis of a series of fluorescent $\beta$-cyclodextrins. Tetrahedron 2005, 61, 3939-3945.

(34) Reizelman, A.; Wigchert, S. C. M.; del-Bianco, C.; Zwanenburg, B. Synthesis and bioactivity of labelled germination stimulants for the 
isolation and identification of the strigolactone receptor. Org. Biomol. Chem. 2003, 1, 950-959.

(35) Casabona, M. G.; Vandenbrouck, Y.; Attree, I.; Couté, Y. Proteomic characterization of Pseudomonas aeruginosa PAO1 inner membrane. Proteomics 2013, 13, 2419-2423. 